\title{
Strategi Pembelajaran Guru Pendidikan Agama Kristen Masa Pandemi Covid-19 di SMAN 1 Damang Batu
}

\author{
Hendri \\ Mahasiswa Institut Agama Kristen Negeri Palangka Raya \\ Email: hendrimarikoi28@gmail.com
}

\begin{abstract}
:
This research aims to describe the strategy of Christian Education teachers in carrying out learning in the covid-19 pandemic. This research method is qualitative research with a qualitative descriptive approach. The data collection techniques used are in-depth interview and documentation techniques. The results showed that the learning strategy used by PAK teachers in SMAN 1 Damang Batu is an expository learning strategy with components that include: introduction, information delivery, student participation, tests (evaluation), as well as KKM follow-up activities. Then, it was found that the efforts of the principal in assisting teachers in implementing learning strategies during the covid 19 pandemic, namely by increasing teacher work motivation, performance supervision, and clinical supervision.
\end{abstract}

Keywords: covid-19; Teacher; Christian religious education; strategy

\begin{abstract}
Abstrak:
Penelitian ini bertujuan untuk mendeskripsikan strategi guru Pendidikan Agama Kristen dalam melaksanakan pembelajaran di masa pandemic covid-19. Metode penelitian ini adalah penelitian kualitatif dengan pendekatan deskriptif kualitatif. Teknik pengumpulan data yang digunakan adalah teknik wawancara mendalam dan dokumentasi. Hasil penelitian menunjukkan bahwa strategi pembelajaran yang digunakan guru PAK di SMAN 1 Damang Batu adalah strategi pembelajaran ekspositori dengan komponen-komponenyang meliputi: pendahuluan, penyampaian informasi, partisipasi peserta didik, tes (evaluasi), serta kegiatan lanjutan KKM. Kemudian, ditemukan upaya kepala sekolah dalam membantu guru dalam melaksanakan strategi pembelajaran dimasa pandemi covid 19 yaitu dengan peningkatan motivasi kerja guru, pengawasan kinerja, serta supervisi klinis.
\end{abstract}

Kata Kunci: covid-19; guru; pendidikan agama kristen; strategi

\section{Pendahuluan}

Pembelajaran merupakan suatu kegiatan belajar mengajar yang dilakukan antara pendidik dan peserta didik untuk mencapai tujuan pendidikan. Proses pembelajaran yang baik membutuhkan strategi pembelajaran yang sesuai dengan karakteristik dan kebutuhan peserta didik. Strategi pembelajaran merupakan suatu cara yang telah direncanakan untuk digunakan oleh seorang guru secara kontekstual yang sesuai dengan kebutuhan peserta didik, kondisi lingkungan serta tujuan yang telah direncanakan dalam proses pembelajaran. ${ }^{1}$

\footnotetext{
${ }^{1}$ Sri Anitah W., Strategi Pembelajaran di SD (Jakarta: Universitas Terbuka, 2007), 1-3.
} 
Guru merupakan seorang yang menentukan keberhasilan belajar peserta didik. $^{2}$ Guru adalah pendidik profesional dengan tugas utama mendidik, mengajar, membimbing, mengarahkan, melatih, menilai, dan mengevaluasi peserta didik pada pendidikan anak usia dini jalur pendidikan formal, pendidikan dasar, dan pendidikan menengah (Undang-undang Nomor 14 Tahun 2005 tentang guru dan dosen). ${ }^{3}$ Berbagai upaya telah dilakukan oleh pemerintah untuk mengatasi penyebaran pandemi Covid-19, dimulai dari lockdown yang mengharuskan sebuah wilayah menutup akses masuk maupun keluar sepenuhnya. Hingga pemerintah mengeluarkan Permenkes No. 9 Tahun 2020 tentang Pembatasan Sosial Berskala Besar (PSBB). Selain itu untuk melawan Covid-19 pemerintah mengeluarkan Peratuan Nomor 4 Tahun 2020 tentang Pelaksanaan Kebijakan Pendidikan dalam Masa Darurat Penyebaran Corona virus Disease (Covid-19). ${ }^{4}$

Pandemi Covid-19 di Indonesia membuat sekolah tidak dapat melaksanakan kegiatan belajar mengajar secara langsung (tatap muka). Agar pembelajaran tetap dapat dilaksanakan, guru melaksanakan proses pembelajaran dengan salah satu metode yang dianggap lebih efektif dalam pembelajaran yaitu secara luar jaringan (luring). Hal tersebut sesuai dengan Surat Edaran Sekretaris Jenderal No. 15 Tahun 2020 tentang pedoman pelaksanaan belajar dari rumah selama darurat bencana Corona Virus Disease (Covid-19) yang dalam pelaksanaannya menggunakan pembelajaran jarak jauh salah satunya adalah pembelajaran luar jaringan (luring). ${ }^{5}$

Permendikbud Nomor 24 Tahun 2012 tentang Penyelenggaraan pendidikan jarak jauh pada pendidikan tinggi, menjelaskan bahwa pendidikan jarak jauh (PJJ) adalah pendidikan yang peserta didiknya terpisah dari pendidik dan pembelajarannya menggunakan berbagai sumber melalui teknologi informasi dan komunikasi serta media lain. Pembelajaran luar jaringan dapat diartikan sebagai suatu kegiatan pembelajaran yang dilakukan tanpa menggunakan akses internet. Kemendikbud tahun 2020 menyebutkan suatu kegiatan pembelajaran dengan menggunakan pembelajaran luring atau offline merupakan pembelajaran yang dilakukan diluar tatap muka oleh guru dan peserta didik. Dilakukan secara offline yang memiliki arti seorang guru memberikan materi berupa hardcopy kepada peserta didik kemudian materi tersebut dipelajari di rumah. ${ }^{6}$

2 Abdul Majid, Perencanaan Pembelajaran (Bandung: Remaja Rosdakarya, 2008), 10.

${ }^{3}$ Undang-undang Nomor 14 Tahun 2005 tentang guru dan dosen.

${ }^{4}$ Peraturan Menteri Kesehatan Republik Indonesia Nomor 9 Tahun 2020 tentang Pedoman Pembatasan Sosial Berskala Besar dalam rangka Percepatan Penanganan Corona Virus Disease 2019 (COVID-19), diakses dari (https://covid19.go.id/p/regulasi/permenkes-no-9-tahun-2020-tentangpedoman-psbb-dalam-rangka-percepatan-penanganan-covid-19, pada tanggal 26 Februari 2021).

${ }^{5}$ Surat Edaran Sekretaris Jenderal No. 15 Tahun 2020 tentang Pedoman Pelaksanaan Belajar dari Rumah selama Darurat Bencana Corona Virus Disease (Covid-19).

6 Permendikbud Nomor 24 Tahun 2012 tentang Penyelenggaraan Pendidikan Jarak Jauh pada Pendidikan Tinggi. 
Keadaan seperti ini merupakan sebuah tantangan dan wajah baru bagi pelaksanaan pendidikan. Kegiatan pembelajaran yang mengikuti peraturan dan kebijakan yang baru memerlukan strategi yang tepat sehingga dalam keadaan inipun proses pembelajaran tetap dapat dilaksanakan guna mendukung agar perkembangan peserta didik dapat mencapai hasil yang diharapkan.

SMAN 1 Damang Batu Kabupaten Gunung Mas, sebuah Sekolah Menengah Atas yang terletak di kelurahan Tumbang Marikoi, kecamatan Damang Batu, kabupaten Gunung Mas. SMAN 1 Damang Batu merupakan salah satu sekolah yang juga terdampak pada pandemi covid- 19 yang harus melaksanakan kegiatan pembelajaran luring. Berdasarkan hasil wawancara awal dengan guru PAK di SMAN 1 Damang Batu Kabupaten Gunung Mas, banyak permasalahan yang dihadapinya dalam melaksanakan kegiatan pembelajaran pada masa pandemi Covid-19 ini. Di antaranya, menurunnya semangat belajar siswa selama pandemi. Dibuktikan dengan semakin sedikitnya siswa yang mengumpulkan tugas yang harus dikerjakan selama belajar di rumah. Waktu yang diberikan oleh sekolah agar siswa belajar di rumah malah digunakan untuk bermain dengan teman-teman seusia, atau membantu orang tua untuk bekerja, dan mengabaikan tugas belajar.

Dari permasalahan tersebut diperlukan strategi pembelajaran yang tepat, sehingga dapat meminimalisir dampak yang akan muncul selanjutnya, seperti: rendahnya kualitas pendidikan karena minat belajar siswa sangat kurang. Lahirnya lulusan-lulusan yang tidak berdaya saing. Dalam hal ini strategi pembelajaran adalah salah satu kajian dan perhatian yang sangat penting. Dengan adanya kajian tentang strategi pembelajaran yang digunakan guru pada sebuah lembaga pendidikan. Maka akan menjadi sebuah bahan pemahaman dalam pelaksanaan pendidikan dimasa pandemi. Tentang bagaimana seharusnya strategi pembelajaran yang harus digunakan untuk meningkatkan mutu pendidikan dalam kondisi pandemi covid 19.

\section{Medote}

Penelitian ini merupakan jenis penelitian kualitatif. Penelitian kualitatif merupakan jenis penelitian yang temuan-temuannya tidak diperoleh melalui prosedur statistik atau bentuk hitungan. Pendekatan kualitatif ini sering disebut penelitian naturalistik karena penelitiannya dilakukan pada kondisi yang alamiah (Naturall Setting), data yang terkumpul bersifat kualitatif. ${ }^{7}$ Data pendekatan deksriptif berupa deksripsi gejala sosial yang telah diinterprestasikan. Berupa deskripsideskripsi hasil temuan, data temuan dalam penelitian ini yaitu deskripsi Strategi guru PAK dalam melaksanakan pembelajaran di masa pandemi covid-19 di SMAN 1 Damang Batu Kabupaten Gunung Mas dan upaya kepala sekolah untuk membantu

${ }^{7}$ Afifuddin dan Beni Ahmad Saebeni, Metodologi Penelitian Kualitatif (Bandung: Pustaka Setia, 2012), 56-57. 
guru untuk melaksanakan strategi tersebut. Sumber data dalam penelitian ini terdiri dari tiga subyek, yang pertama yaitu bersumber dari kepala sekolah, yang kedua 1 (satu) orang guru PAK, dan yang ketiga adalah 3 (tiga) orang peserta didik dari kelas $\mathrm{X}$ dan $\mathrm{XI}$, jumlah total peserta didik 6. Jumlah keseluruhan sumber data adalah 8 orang.

\section{Hasil dan Pembahasan}

\section{Hasil}

\section{Strategi Pembelajaran}

Secara umum strategi pembelajaran adalah suatu kegiatan perencanaan pembelajaran yang harus dikerjakan guru dan siswa agar tujuan pembelajaran dapat tercapai secara efektif dan efisien. Menurut Sanjaya ada beberapa macam strategi pembelajaran yang dilakukan oleh seorang guru, berikut ini jenis-jenis strategi pembelajaran: ${ }^{8}$ pertama, Strategi Pembelajaran Ekspositori. Strategi pembelajaran ekspositori adalah strategi pembelajaran yang menekankan kepada proses penyampaian materi secara verbal dari seorang guru kepada kelompok peserta didik dengan maksud agar peserta didik dapat menguasai materi pelajaran secara optimal. Dalam sistem ini guru menyajikan dalam bentuk yang telah dipersiapkan secara rapi dan guru lebih berperan aktif dalam pembelajaran, sedangkan peserta didik hanya mendengarkan, menyimak dan mencernanya saja secara tertib dan teratur. Langkahlangkah pembelajaran ekspositori dimulai dari persiapan, penyajian, korelasi, menyimpulkan dan menerapkan.

Strategi pembelajaran ekspositori merupakan bentuk dari pendekatan pembelajaran yang berorientasi kepada guru (teacher centered approach). Dikatakan demikian, sebab dalam strategi ini guru memegang peran yang sangat dominan. Melalui strategi ini guru menyampaikan materi pembelajaran secara terstruktur dengan harapan materi pelajaran yang disampaikan itu dapat dikuasai siswa dengan baik. Fokus utama strategi ini adalah kemampuan akademik (academic achievement) siswa. Metode pembelajaran yang digunakan dalam strategi ekspositori disebut juga dengan metode ceramah. ${ }^{9}$ Terdapat beberapa karakteristik strategi pembelajaran ekspositori di antaranya:

1. Strategi ekspositori dilakukan dengan cara menyampaikan materi pelajaran secara verbal, artinya bertutur secara lisan merupakan alat utama dalam melakukan strategi ini, oleh karena itu sering orang mengidentikkannya dengan ceramah.

8 Wina Sanjaya, Strategi Pembelajaran Berorientasi Standar Proses Pendidikan (Jakarta: Kencana Prenada Media Group, 2007), 214.

9 Sanjaya, 118. 
2. Biasanya materi pelajaran yang disampaikan adalah materi pelajaran yang sudah jadi, seperti data atau fakta, konsep-konsep tertentu yang harus dihafal sehingga tidak menuntut siswa untuk berpikir ulang.

3. Tujuan utama pembelajaran adalah penguasaan materi pelajaran itu sendiri. Artinya, setelah proses pembelajaran berakhir siswa diharapkan dapat memahaminya dengan benar dengan cara dapat mengungkapkan kembali materi yang telah diuraikan. ${ }^{10}$

Langkah-langkah pembelajaran ekspositori adalah sebagai berikut: ${ }^{11}$

a) Persiapan (Preparation)

Tahap persiapan berkaitan dengan mempersiapkan siswa untuk menerima pelajaran. Dalam strategi ekspositori, langkah persiapan merupakan langkah yang sangat penting. Keberhasilan pelaksanaan pembelajaran dengan menggunakan strategi ekspositori sangat tergantung pada langkah persiapan. Beberapa hal yang harus dilakukan dalam langkah persiapan di antaranya adalah: berikan sugesti yang positif dan hindari sugesti yang negatif, mulailah dengan mengemukakan tujuan yang harus dicapai, serta bukalah file dalam otak siswa.

b) Penyajian (Presentation)

Langkah penyajian adalah langkah penyampaian materi pelajaran sesuai dengan persiapan yang telah dilakukan. Dalam penyajian ini adalah bagaimana agar materi pelajaran dapat dengan mudah ditangkap dan dipahami oleh siswa. Karena itu, ada beberapa hal yang harus diperhatikan dalam pelaksanaan langkah ini, yaitu penggunaan bahasa, intonasi suara, menjaga kontak mata dengan siswa, dan menggunakan joke-joke yang menyegarkan.

c) Korelasi (Correlation)

Langkah korelasi adalah langkah menghubungkan materi pelajaran dengan pengalaman siswa atau dengan hal-hal lain yang memungkinkan siswa dapat menangkap keterkaitannya dalam struktur pengetahuan yang telah di-milikinya. Langkah korelasi dilakukan untuk memberikan makna terhadap materi pelajaran, baik makna untuk memperbaiki struktur pengetahuan yang telah dimilikinya maupun makna untuk meningkatkan kualitas kemampuan berpikir dan kemampuan motorik siswa.

d) Menyimpulkan (Generalization)

Menyimpulkan adalah tahapan untuk memahami inti dari materi pelajaran yang telah disajikan. Langkah menyimpulkan merupakan langkah yang sangat penting dalam strategi ekspositori, sebab melalui langkah menyimpulkan siswa akan dapat mengambil inti sari dari proses penyajian.

e) Mengaplikasikan (Application)

\footnotetext{
${ }^{10}$ Made Wena, Strategi Pembelajaran Inovatif Kontemporer (Jakarta: Bumi Aksar , 2011), 15.

11 Sanjaya, 302.
} 
Langkah aplikasi adalah langkah unjuk kemampuan siswa setelah mere-ka menyimak penjelasan guru. Langkah ini merupakan langkah yang sangat penting dalam proses pembelajaran ekspositori, sebab melalui langkah ini guru akan dapat mengumpulkan informasi tentang penguasaan dan pemahaman materi pelajaran oleh siswa. Teknik yang biasa dilakukan pada langkah ini di antaranya: (1) memberikan tugas yang relevan dengan materi yang telah disajikan, (2) memberikan tes yang sesuai dengan materi pelajaran yang telah disajikan.

Adapun model pembelajaran ekspositori adalah pembelajaran berpusat pada guru. Pembelajaran ekspositori merupakan proses pembelajaran yang lebih berpusat pada pendidik (teacher centered), pendidik menjadi sumber dan pemberi informasi utama.

\section{Data Lapangan}

Berdasarkan penelitian yang dilakukan berikut adalah hasil penelitian yang dapat peneliti paparkan. Berkaitan dengan rumusan masalah dan tujuan penelitian yaitu mendeskripsikan strategi guru PAK dalam melaksanakan pembelajaran di masa pandemi covid-19 di SMAN 1 Damang Batu Kabupaten Gunung Mas serta mendeskripsikan upaya sekolah dalam membantu guru melaksanakan strategi pembelajaran di masa pandemi covid-19 di SMAN 1 Damang Batu Kabupaten Gunung Mas. Data penelitian berupa deskripsi hasil wawancara kepada Kepala SMAN 1 Damang Batu, Guru PAK dan peserta didik di SMAN 1 Damang Batu.

1. Strategi Guru PAK dalam Melaksanakan Pembelajaran di Masa Pandemi Covid-19 di SMAN 1 Damang Batu Kabupaten Gunung Mas.

Data penelitian adalah data berupa deskripsi strategi pembelajaran yang digunakan oleh guru PAK di SMAN 1 Damang Batu. Dalam hal ini berupa deskripsi komponen strategi pembelajara yang meliputi, (a) Pendahuluan, (b) Penyampaian Informasi, (c) Partisipasi Peserta didik, (d) Tes (evaluasi) dan Kegiatan lanjutan.

a. Pendahuluan

Tahap pendahuluan yang dilakukan oleh Iga Karolina, selaku guru PAK di SMAN 1 Damang Batu, langkah awal adalah merancang pembelajaran dengan mempelajari lebih dulu materi yang akan diberikan. Kemudian tentukan model pembelajaran yang cocok apa saja. Misalnya pembelajaran tentang "kasih". Dipahami terlebih dahulu, apa saja contoh kasus pribadi yang mengasihi. Kemudian menentukan indikator capaian dan tujuan pembelajaran, langkah-langkah pembelajaran, model pembelajaran yang tepat, agar siswa banyak terlibat dalam 
kegiatan pembelajaran. Selanjutnya adalah menentukan teknik penilaian atau evaluasi. ${ }^{12}$

Kemudian diungkapkan oleh Dores, Siswa kelas XI IPA SMAN 1 Damang Batu, saat dilontarkan pertanyaan, terkait rancangan pembelajaran yang dibuat guru, apakah mendorong mereka terpacu untuk belajar. Dores mengemukakan bahwa "Tidak", dia mengaku bahwa akhir-akhir ini mereka banyak diberikan tugas oleh guru untuk dikerjakan di rumah. Sebab waktu belajar di sekolah sangat terbatas". ${ }^{13}$ Kemudian Delta Oktavia siswi kelas X IPA ketika dilontarkan pertanyaan yang serupa, menjawab “tidak, kadang-kadang. hanya mendengar apa yang dijelaskan oleh guru saja, setelah itu diberi tugas dan mengerjakannya di rumah masing-masing". ${ }^{4}$ Sedangkan Debora Agustina Asihai siswi kelas XI IPA menjawab kadang-kadang, tidak semua. ${ }^{15}$

Sedangkan jawaban yang diperoleh dari Dina Diniati siswi kelas X IPS SMAN 1 Damang Batu, dia mengakui rancangan yang dibuat oleh guru membuat dia sebagai siswa menjadi termotivasi. Berdasarkan hasil wawancara tersebut dapat disimpulkan bahwa dalam melaksanakan kegiatan pendahaluan atau merancang kegiatan pembelajaran guru PAK memulai dengan mempelajari terlebih dahulu materi yang akan diberikan, kemudian dengan menentukan indikator, tujuan dan model pembelajaran yang tepat dan menentukan teknik penilaian atau evaluasi. Selanjutnya berdasarkan hasil wawancara kepada beberapa siswa/siswi kelas X maupun kelas XI, dipahami bahwa apakah rancangan pembelajaran yang dibuat guru, membuat mereka terpacu untuk belajar. Dominan mereka menyatakan tidak. Rancangan yang dibuat oleh guru PAK dalam kegiatan belajar lebih cenderung memberikan penugasan.

\section{b. Penyampaian Informasi}

Teknik menyampaikan informasi, melaksanakan pembelajaran di dalam kelas Iga Karolina guru PAK SMAN 1 Damang Batu menyatakan bahwa metode yang sering digunakan adalah metode ceramah di dalam kelas. Selain itu dengan mengajak peserta didik diskusi. ${ }^{16}$ Selanjutnya Iga Karolina juga mengungkapkan bahwa dirinya, dalam melaksanakan pembelajaran bersama siswa di dalam kelas. Terkadang menjadikan contoh kejadian nyata dalam kehidupan sehari-hari. Untuk dijadikan sebuah contoh kasus agar siswa dapat dengan mudah memahami, dapat berupa

12 Wawancara, Guru Pendidikan Agama Kristen. Rabu, 11/08/2021, 08:03 WIB. Ruangan Kelas X MIA. SMA Negeri 1 Damang Batu.

${ }^{13}$ Wawancara, siswa SMA Negeri 1 Damang Batu. Rabu, 11/08/2021. 09: 00 WIB. Ruangan Kelas XI IPA. SMA Negeri 1 Damang Batu.

14 Wawancara, siswi SMA Negeri 1 Damang Batu. Kamis, 12/08/2021. 09:51 WIB. Ruangan Kelas X MIA. SMA Negeri 1 Damang Batu.

${ }_{15}$ Wawancara, siswi SMA Negeri 1 Damang Batu. Kamis, 12/08/2021. 10:38 WIB. Ruangan Kelas XI IPS. SMA Negeri 1 Damang Batu.

16 Ibid. 
pengalaman secara pribadi atau dari kejadian yang ditemukan di lingkungan masyarakat. Selanjutnya didukung juga oleh bahan-bahan dari buku mata pelajaran beliau miliki. ${ }^{17}$

Kemudian terkait cara memposisikan diri di dalam kelas Iga Karolina mengakui bahwa menurutnya otoritas seorang pendidik dalam proses pembelajaran cukup penting. Akan tetapi bukan otoritas yang sifatnya menghilangkan hak-hak peserta didik. Melainkan otoritas yang penuh toleran dan penghargaan terhadap seluruh peserta didik. Tugas guru sebagai pimpinan di dalam kelas maupun di luar kelas memang tidak dapat dihilangkan. Sebab dengan otoritas tersebut seorang guru dipandang sebagai seorang yang harus dihormati dan dihargai. Akan tetapi yang lebih penting adalah bagaimana otoritas tersebut dibarengi dengan kualitas. Sehingga guru digugu dan ditiru bukan hanya karena profesi yang melekat padanya akan tetapi memang karena tindak tutur dan bahasa serta kualitasnya diakui dapat ditiru dengan baik. ${ }^{18}$

Kemudian kepada Delta Oktavia siswi kelas X IPA SMAN 1 Damang Batu, setelah dilontarkan pertanyaan apakah guru sering menggunakan metode ceramah ketika memberikan pembelajaran didalam kelas, Delta menyatakan bahwa ya dalam setiap pembelajaran berlangsung guru selalu menggunakan metode ceramah. ${ }^{19}$

Kemudian jawaban serupa diperoleh dari Dina Diniati siswi kelas X IPA SMAN 1 Damang Batu, Dina menjawab Ya, guru sering menggunakan metode ceramah.. sebab guru sering menggunakan metode ini. Berdasarkan data tersebut dapat disimpulkan bahwa Pada komponen penyampaian informasi ini guru menentukan metode ceramah. Kemudian cara guru memposisikan diri diantara siswa ketika berada didalam kelas dengan mengesampingkan otoritas sebagai seorang guru, dengan menghargai dan memberikan apresiasi kepada peserta didik yang mendapatkan pencapaian tertentu dalam pembelajaran.

c. Pasrtisipasi Peserta didik

Dipaparkan oleh Iga Karolina bahwa dirinya sebagai seorang pendidik, tentu ikut serta mengupayakan suasana belajar yang dapat meningkatkan kreatifitas dan partisipasi siswa. Upaya-upaya tersebut dapat berupa menyediakan wadah atau kegiatan di luar kegiatan belajar. Misalnya mengirim dan mendampingi siswa dalam seleksi paskibraka, membimbing siswa untuk mengikuti lomba-lomba tingkat kecamatan maupun kabupaten. ${ }^{20}$ Melalui dukungan-dukungan semacam itu ia berharap adanya kematangan dari kreatifitas pada diri siswa. Hal ini akan membuat siswa mau untuk berpartisipasi. Kemudian ketika dilontarkan pertanyaan apakah

\footnotetext{
17 Ibid.

18 Ibid.

19 Ibid.

20 Ibid.
} 
peserta didik mau terlibat aktif dalam kegiatan belajar, jawabannya, iya, sejauh ini peserta didik mau terlibat aktif dalam kegiatan pembelajaran. ${ }^{21}$ Kemudian Dina Diniati siswi kelas X IPS ketika ditanya apakah metode yang guru gunakan di dalam kelas bertujuan untuk memacu siswa belajar mandiri dalam mencari sumber-sumber dan referensi belajar? Jawabnya ya, guru menerapkan hal tersebut. ${ }^{22}$

Berdasarkan data penelitian tersebut dapat dipahami bahwa upaya guru PAK dalam mewujudkan peserta didik yang aktif dan mau berpartisipasi. Dengan menyediakan wadah atau kegiatan diluar kegiatan belajar, misalnya mengirim dan mendampingi siswa dalam seleksi paskibraka, membimbing siswa untuk mengikuti lomba-lomba tingkat kecamatan maupun kabupaten. Kemudian berupaya memotivasi peserta didik untuk semangat menempuh pendidikan.

d. Tes (evaluasi) dan kegiatan lanjutan.

Diungkapkan oleh Iga Karolina bahwa dalam hal melaksanakan penilaian pembelajaran, evalusi biasanya dari tugas-tugas harian. Kemudian yang paling penting adalah lebih pada sikap. Karena kalau mengharapkan dari nilai harian sudah tentu tidak cukup dan biasanya kalau ulangan itu ada sebagian siswa yang tidak mencapai KKM, akhirnya kebanyakan dibantu guru. Kemudian untuk mengukurnya itu lebih pada sikap peserta didik, bagaimana kesehariannya di sekolah maupun kesehariannya di luar lingkungan sekolah juga diamati. Karena Agama ini yang terpenting itu adalah ahlak. ${ }^{23}$

Kemudian diungkapkan oleh Dores siswa kelas X IPA SMAN 1 Damang Batu bahwa teknik penilaian yang dilakukan guru adalah soal uraian dan pilihan ganda. Tapi yang sering diberikan itu soal uraian pilihan ganda jarang. ${ }^{24}$ Pendapat tersebut diperkuat oleh Chrisna Akuila kalau untuk pembelajaran Agama itu essay dan PG. ${ }^{25}$ Berdasarkan data tersebut dapat disimpulkan bahwa dalam komponen evaluasi dan kegiatan lanjutan adalah nilai peserta didik pada mata pelajaran PAK di SMAN 1 Damang Batu. Dibantu dengan menilai indikator sikap, untuk membantu siswa/siswi yang tidak tuntas KKM. Selanjutnya bentuk tes yang digunakan adalah tes uraian dan pilihan ganda.

e. Strategi Pembelajaran Ekspositori

1) Peserta didik hanya mendengarkan, menyimak dan mencerna secara tertib dan teratur. Tugas siswa hanya memahami bukan untuk mencari tahu lebih lanjut mengenai materi yang diajarkan. Sehingga tidak ada ruang untuk kreatifitas siswa.

21 Ibid.

22 Ibid.

23 Ibid.

24 Ibid.

25 Wawancara, siswi SMA Negeri 1 Damang Batu. Kelas X MIA. Kamis, 12/08/2021. 09:54 WIB. Ruangan kelas X MIA, SMA Negeri 1 Damang Batu. 
Data tentang kreatifitas siswa dikemukakan oleh Dores siswa kelas X IPA SMAN 1 Damang Batu. Kalau dikatakan aktif sih tidak selama pembelajaran di masa pandemi ini. Kami hanya mendengarkan perintah dari guru saja dan melakasanakan tugas kami di rumah saja. Itu saja kegiatan kami selama pembelajaran saat ini, dan hal yang seperti ini saya rasa sangat membosankan rasanya kami dikekang oleh keadaan yang seperti ini dan tidak bisa berbuat banyak. ${ }^{26}$

2) Kemudian diperkuat oleh pernyataaan Delta Oktavia siswi kelas X IPA SMAN 1 Damang Batu, "Masih sangat kurang dikarenakan pada saat kegiatan belajar. Guru hanya sering menjelaskan dibandingkan dengan memberikan kegiatan kreatifitas" ${ }^{27}$ Lalu ketika ditanya tentang apakah metode yang digunakan guru didalam kelas memacu supaya aktif belajar jawab Delta Oktavia "Tidak, pada dasarnya guru kami hanya menggunakan metode ceramah saja." Berdasarkan hasil wawancara tersebut dapat disimpulkan bahwa tidak diterapkannya strategi pembelajaran yang dapat memacu kreatifitas peserta didik di dalam pembelajaran PAK SMAN 1 Damang Batu di masa pandemi.

3) Peran guru dalam pembelajaran lebih dominan dan metode yang digunakan adalah metode ceramah. Data tentang indikator ini dibuktikan dengan hasil wawancara kepada Iga Karolina, ketika ditanya apakah menggunakan metode ceramah di dalam kelas jawabannya adalah "Iya, saya menggunakan metode ceramah di dalam kelas". ${ }^{28}$ Didukung oleh pendapat Delta Oktavia siswi kelas X IPA "Ya, dalam setiap pembelajaran berlangsung guru selalu menggunakan metode ceramah". ${ }^{29}$ Kemudian pendapat Debora Agustina Asihai, siswi kelas XI IPS "Ya, kalau tidak ceramah yah... hanya diberikan tugas itu saja." 30 Berdasarkan hasil wawancara tersebut dapat dipahami bahwa di dalam kelas peserta didik hanya mendengarkan apa yang disampaikan guru. Serta pembelajaran yang berlangsung adalah pembelajaran yang berpusat pada guru. Dengan kegiatan akhir pembelajaran adalah menggunakan metode penugasan.

4) Pada tahap mengaplikasikan menggunakan tugas uraian dan pilihan ganda. Data tentang penilaian pembelajaran seperti yang dikemukakan oleh Chirna Akuila siswi kelas X IPA SMAN 1 Damang Batu. Menyatakan bahwa kalau penilaian untuk pembelajaran Agama itu essay dan PG. ${ }^{31}$ hal yang serupa diungkapkan oleh Dina Diniati bahwa guru menggunakan penugasan dengan essay dan PG. ${ }^{32}$ Kemudian diungkapkan oleh Dores siswa kelas XI IPA SMAN 1 Damang Batu menyatakan

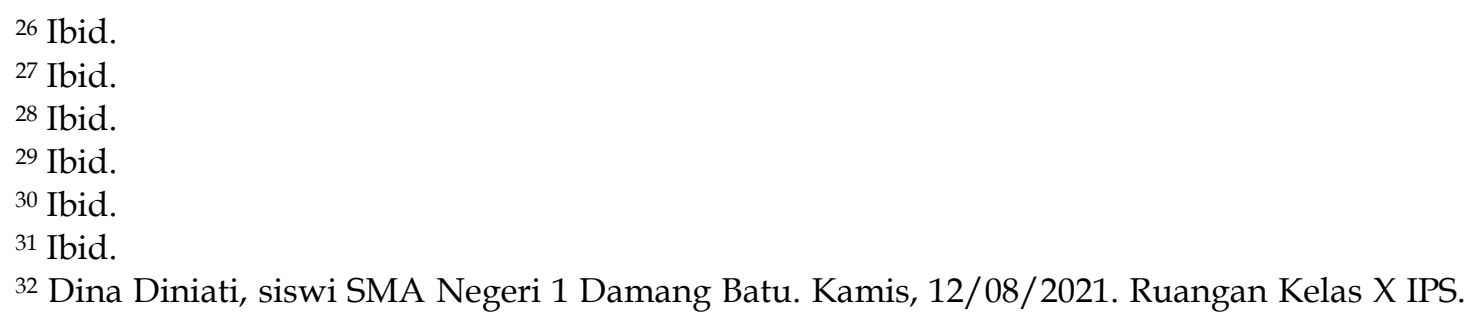

32 Dina Diniati, siswi SMA Negeri 1 Damang Batu. Kamis, 12/08/2021. Ruangan Kelas X IPS. SMA Negeri 1 Damang Batu. 
bahwa soal yang diberikan oleh guru itu essay dan pilihan ganda. Tapi yang sering diberikan itu soal essay pilihan ganda jarang". ${ }^{33}$ Berdasarkan hasil wawancara tersebut sejalan dengan karakteristik strategi pembelajaran ekspositori yaitu menggunakan penilaian dengan penugasan essay dan pilihan ganda.

2. Upaya Sekolah dalam membantu Guru Melaksanakan Strategi Pembelajaran di Masa Pandemi Covid-19 di SMAN 1 Damang Batu Kabupaten Gunung Mas.

Data penelitian tentang upaya yang dapat dilakukan oleh sekolah untuk membantu guru dalam melaksanakan pembelajaran di masa pandemi covid-19 adalah berupa deskripsi. Dalam hal ini indikator penelitian yang digunakan adalah pada upaya kepala sekolah untuk meningkatkan kemampuan profesional guru. Kegiatan atau upaya yang dapat dilakukan oleh kepala sekolah untuk meningkatkan kompetensi profesionalisme guru tersebut yaitu, peningkatan kemampuan profesional guru (pemberdayaan), Supervisi klinik (supervisi klinis adalah upaya kepala sekolah selaku suvervisor untuk memantau dan membantu guru memperbaiki diri jika ada kendala yang dihadapi dalam proses mengajar) dam peningkatan motivasi kerja guru. ${ }^{34}$

a. Peningkatan kemampuan profesional guru (pemberdayaan).

Berkaitan dengan peningkatan kemampuan professional guru, ketika dilontarkan pertanyaan terkait pemberdayaan guru dimasa pandemi, "kalau dari sekolah sendiri belum ada. Karena memang tidak ada agenda khusus atau arahan langsung dari dinas terkait hal tersebut. Akan tetapi teknis kegiatan belajar mengajar dalam bentuk surat dari dinas sudah ada masing-masing guru memegangnya. Sehingga surat tersebut yang selalu menjadi pedoman dalam melaksanakan kegiatan belajar mengajar dimasa pandemi ini. Sekaligus melihat situasi perkembangan kasus covid 19 di Tumbang Marikoi sendiri."35 Berdasarkan hasil wawancara kepada kepala sekolah tersebut dapat dipahami bahwa bagi guru-guru SMAN 1 Damang Batu, belum adanya pemberdayaan tentang cara mengajar dimasa pandemi. Guru-guru berpedoman pada surat edaran dari dinas terkait pemberlakuan protokol kesehatan di sekolah.

b. Supervisi klinik (supervisi klinis adalah upaya kepala sekolah selaku suvervisor untuk memantau dan membantu guru mengatasi jika ada kendala yang dihadapi dalam proses mengajar).

Kesulitan yang dihadapi guru di masa pandemi adalah harus melaksankan kegiatan belajar dengan mematuhi protokol kesehatan. Menggunakan masker,

33 Ibid.

${ }^{34}$ Bafadal Ibrahim, Peningkatan Profesionalisme Guru Sekolah Dasar (Jakarta: Bumi Aksara, 2006), 41.

${ }^{35}$ Rodie, Kepala sekolah SMA Negeri 1 Damang Batu. Rabu, 25/05/2021. 10:20 WIB. Ruangan Kepala sekolah SMA Negeri 1 Damang Batu. 
mengurangi kerumunan. Mengurangi mobilitas masa. Sehingga yang dibutuhkan selama masa pandemi adalah atribut-atribut kesehatan, misalnya masker, hand sanitizer, sabun cuci tangan, air, tong, thermometer gun. Berdasarkan wawancara dengan kepala sekolah, beliau mengatakan bahwa untuk fasilitas, SMAN 1 Damang Batu mendapatkan dari dinas kesehatan terdekat. Misalnya hand sanitizer, tong pencuci tangan dan sabun, serta masker bagi guru-guru. Selanjutnya termometer gun untuk mengukur suhu. Hal tersebut membuktikan bahwa atribut kesehatan di SMAN 1 Damang Batu.

c. Pengawasan Kinerja Guru

Terkait dengan pengawasan, berikut pengakuan dari kepala SMAN 1 Damang Batu, ketika ditanya bagaimana strategi yang diterapkan untuk mengawas kinerja guru. Jawaban beliau, dalam mengawasi kinerja guru, tidak ada agenda khusus. Karena setiap guru-guru ini kalau ada kegiatan yang menyebabkan tidak dapat melaksanakan tugas mengajar pasti terlebih dahulu ijin. Kemudian untuk mengawasi kegiatan guru di sekolah, jika tidak ada kesibukan, beliau juga jalan-jalan ke ruangan ruangan. Begitu saja. Selebihnya dengan menilai daftar hadir sebagai bukti kehadiran guru. ${ }^{36}$

d. Peningkatan Motivasi Kerja Guru

Adapun upaya yang dilakukan kepala SMAN 1 Damang Batu dalam memotivasi guru adalah, dengan melakukan monitoring secara rutin di sekolah. Bagi guru-guru yang piket, memberikan biaya konsumsi. Selebihnya melakukan komunikasi tentang apa saja kendala yang mungkin dihadapi guru-guru dan berusaha membantu memecahkan persoalan tersebut. Berdasarkan hasil wawancara tersebut dapat disimpulkan bahwa perhatian kepala sekolah terhadap motivasi guru di SMAN 1 Damang Batu cukup. Dibuktikan dengan berbagai upaya motivasi yang telah dilakukan. ${ }^{37}$

\section{Pembahasan}

Strategi guru PAK dalam Melaksanakan Pembelajaran di masa Pandemi Covid-19 di SMAN 1 Damang Batu Kabupaten Gunung Mas

Teori yang digunakan sebagai indikator penelitian adalah teori komponen strategi yang diungkapkan oleh Dick dan Carey dalam Hamzah yang meliputi: (a) Pendahuluan, (b) Penyampaian informasi, (c) Partisipasi Peserta didik, (d) Tes (evaluasi) dan kegiatan lanjutan (follow up) memperbaiki nilai peserta didik yang tidak tuntas KKM. ${ }^{38}$

36 Ibid.

37 Ibid.

38 Dick and Carey, Komponen Strategi Pembelajaran. http:/ Komponen strategi pembelajaran /2005/08/17/. Diakses tanggal 18 Agustus 2021 (03: 12 WIB) 
a. Pendahuluan meliputi cara guru merancang pembelajaran, memberikan gambaran awal kegiatan belajar yang akan dilaksanakan kepada peserta didik. Cara guru menjelaskan indikator dan tujuan pembelajaran. Cara memotivasi peserta didik sebelum memulai kegiatan belajar. Berdasarkan data penelitian yang telah dipaparkan sebelumnya, dibagian pendahuluan dalam hal merancang pembelajaran dilakukan guru dengan mempelajari materi ajar terlebih dahulu. Kemudian menentukan indikator dan tujuan pembelajaran, menentukan model pembelajaran dan teknik penilaian.

b. Kedua adalah penyampaian informasi, pada kegiatan ini guru harus memahami situasi dan kondisi yang dihadapinya. Agar informasi yang disampaikan dapat diserap dan dipahami oleh peserta didik. Pada komponen penyampaian informasi ini guru menentukan model pembelajaran yang tepat dan cara menyampaikan materi kepada peserta didik. Kemudian cara guru memposisikan diri diantara siswa ketika berada didalam kelas. Berdasarkan hasil penelitian pada komponen penyampaian informasi ini guru menentukan metode pembelajaran yang tepat yaitu metode ceramah dan menyampaikan materi kepada peserta didik dengan menciptakan suasana saling torelan saling menghargai. Kemudian cara guru memposisikan diri diantara siswa ketika berada didalam kelas dengan mengesampingkan otoritas sebagai seorang guru, dengan menghargai dan memberikan apresiasi kepada peserta didik yang mendapatkan pencapaian tertentu dalam pembelajaran. Berdasarkan prinsip student centered peserta didik merupakan pusat dari kegiatan belajar. Bahwa proses pembelajaran akan berhasil apabila peserta didik aktif melakukan latihan yang relevan dengan tujuan pembelajaran yang sudah diterapkan. Berkaitan dengan keaktifan dan partisipasi peserta didik. Latihan dan praktik seharusnya dilakukan setelah peserta didik diberi informasi tentang suatu pengetahuan, keterampilan dan sikap. Agar materi tersebut benar-benar terinternalisasi relatif mantap dan menetap dalam diri mereka) maka kegiatan selanjutnya adalah hendaknya peserta didik diberi kesempatan untuk berlatih atau mempraktikkan pengetahuan, sikap, keterampilan tersebut. 39 Upaya guru PAK SMAN 1 Damang Batu dalam mewujudkan peserta didik yang aktif dan kreatif dan mau berpartisipasi. Upayaupaya tersebut dapat berupa menyediakan wadah atau kegiatan diluar kegiatan belajar, misalnya mengirim dan mendampingi siswa dalam seleksi paskribraka, membimbing siswa untuk mengikuti lomba-lomba tingkat kecamatan maupun kabupaten. Kemudian berupaya memotivasi peserta didik untuk semangat menempuh pendidikannya.

c. Tes (evaluasi) dilaksanakan diakhir kegiatan pembelajaran setelah peserta didik melalui berbagai proses pembelajaran. Pelaksanaan tes juga dilakukan setelah

39 Ibid, 74. 
peserta didik melakukan pembelajaran. Ada dua jenis tes atau penilaian yang biasa dilakukan oleh kebanyakan pendidik, yaitu pretest dan posttest. ${ }^{40}$ Nurani, dkk. Mengemukakan bahwa secara umum tes digunakan oleh pendidik untuk mengetahui apakah tujuan pembelajaran khusus telah tercapai atau belum dan apakah pengetahuan, keterampilan dan sikap telah benar-benar dimiliki peserta didik atau belum. Pelaksanaan tes biasanya dilaksanakan diakhir kegiatan pembelajaran setelah peserta didik melalui berbagai proses pembelajaran, yaitu penjelasan tujuan diawal kegiatan pembelajaran, penyampaian informasi berupa materi pembelajaran. Di samping itu, pelaksanaan tes juga dilakukan setelah peserta didik melakukan latihan atau praktik. ${ }^{41}$ Didalam mata pelajaran PAK jenis tes yang digunakan adalah tes uraian dan pilihan ganda.

d. Kegiatan lanjutan Winaputra mengemukakan bahwa kegiatan lanjutan atau follow up, secara prinsip ada hubungannya dengan hasil tes yang telah dilakukan. Karena kegiatan lanjutan esensinya adalah untuk mengoptimalkan hasil belajar peserta didik. ${ }^{42}$ Dalam mata pelajaran PAK follow up dilakukan dengan menilai aspek sikap, sehingga jika sikap baik, untuk membantu angka KKM. Selanjutnya adalah strategi pembelajaran ekspositori, Strategi pembelajaran ekspositori merupakan bentuk dari pendekatan pembelajaran yang berorientasi kepada guru (teacher centered approach). Dikatakan demikian, sebab dalam strategi ini guru memegang peran yang sangat dominan. Melalui strategi ini guru menyampaikan materi pembelajaran secara terstruktur dengan harapan materi pelajaran yang disampaikan itu dapat dikuasai siswa dengan baik. Fokus utama strategi ini adalah kemampuan akademik (academic achievement) siswa. Metode pembelajaran yang digunakan dalam strategi ekspositori disebut juga dengan metode ceramah. ${ }^{43}$ Hal tersebut adalah tanda-tanda dari pembelajaran ekspositori. Sehingga dapat disimpulkan bahwa strategi guru PAK di SMAN 1 Damang Batu adalah strategi pembelajaran ekspositori dengan komponen-komponen strategi tersebut meliputi pendahuluan, penyampaian informasi, partisipasi peserta didik, tes (evaluasi) dan kegiatan lanjutan (follow up) memperbaiki nilai peserta didik yang tidak tuntas KKM.

Upaya Sekolah dalam membantu Guru Melaksanakan Strategi Pembelajaran di Masa Pandemi Covid-19 di SMAN 1 Damang Batu Kabupaten Gunung Mas

Dalam hal ini indikator penelitian yang digunakan adalah pada upaya kepala sekolah untuk meningkatkan kemampuan profesional guru. Kegiatan atau upaya

${ }^{40} \mathrm{Ibid}, 75$.

${ }^{41}$ Ibid, 74 .

${ }^{42}$ Udin S. Winataputra, dkk., Strategi Belajar Mengajar (Jakarta: Pusat Penerbitan Universitas Terbuka, 2001) 70.

${ }^{43}$ Sanjaya, 118. 
yang dapat dilakukan oleh kepala sekolah untuk meningkatkan kompetensi profesionalisme guru tersebut yaitu, peningkatan kemampuan profesional guru (pemberdayaan), Supervisi klinik (supervisi klinis adalah upaya kepala sekolah selaku suvervisor untuk memantau dan membantu guru memperbaiki diri jika ada kendala yang dihadapi dalam proses mengajar) dam peningkatan motivasi kerja guru. ${ }^{44}$

a. Peningkatan kemampuan profesional guru. Guru profesional adalah guru yang memiliki komponen tertentu sesuai dengan persyaratan yang dituntut oleh profesi keguruan. Guru profesional senantiasa menguasai bahan atau materi pelajaran yang akan diajarkan dalam interaksi belajar mengajar, serta senantiasa mengembangkan kemampuan secara berkelanjutan, baik dalam segi ilmu yang dimilikinya maupun pengalamannya. Sedangkan Profesionalisme guru adalah kemampuan guru untuk melakukan tugas pokoknya sebagai pendidik dan pengajar meliputi kemampuan merencanakan, melakukan, dan melaksanakan evaluasi pembelajaran. ${ }^{45}$

Upaya meningkatkan profesionalisme guru di masa pandemi, yang diperlukan adalah adanya pelatihan bagi guru untuk melaksanakan kegiatan belajar secara efektif dan efisien. Sebab pandemi adalah hal baru dalam dunia pendidikan. Tentu saja membutuhkan pemahaman dan kemampuan yang cukup dalam menjalani tugas ditengah-tengah pandemi agar kegiatan belajar dapat mencapai hasil yang dibutuhkan. Berdasarkan data wawancara kepada kepala SMAN 1 Damang Batu diperoleh data bahwa bagi guru-guru SMAN 1 Damang Batu, belum adanya pemberdayaan tentang cara mengajar dimasa pandemi. Guruguru berpedoman pada surat edaran dari dinas terkait pemberlakuan protokol kesehatan di sekolah.

b. Supervisi klinis adalah kegiatan yang banyak mengandung unsur pembinaan agar pekerjaan yang diawasi diketahui kekurangannya. Supervisi merupakan aktivitas yang harus dilakukan oleh seorang pemimpin atau supervisor berkaitan dengan peran kepemimpinan yang diembannya dalam rangka menjaga kualitas layanan/produk yang dihasilkan lembaga. ${ }^{46}$ Supervisi klinis dalam dunia pendidikan diartikan sebagai upaya kepala sekolah selaku suvervisor untuk memantau dan membantu guru memperbaiki diri jika ada kendala yang dihadapi dalam proses mengajar. Untuk memberdayakan guru-guru dimasa pandemi, SMAN 1 Damang Batu mendapatkan dari dinas kesehatan terdekat. Misalnya hand sanitizer, tong pencuci tangan dan sabun, serta masker bagi guru-guru. Selanjutnya

${ }^{44}$ Ibrahim, Peningkatan profesionalisme guru..., 41.

${ }^{45}$ https://ratnadewi87.wordpress.com/tag/upaya-meningkatkan-profesional-guru/ (diakses 19/08/2021, 18:00 WIB)

${ }^{46}$ Suharsimi Arikunto dan Lia Yuliana, Manajemen Pendidikan (Yogyakarta: Aditya Media, 2008), 370. 
termometer gun untuk mengukur suhu. Hal tersebut membuktikan bahwa atribut kesehatan di SMAN 1 Damang Batu sudah terpenuhi.

c. Pengawasan kinerja guru yang merupakan salah satu tugas dari kepala sekolah. Kepala sekolah berkewajiban menjamin agar guru-guru senantiasa disiplin melaksanakan tugas-tugasnya. Pengawasan tersebut juga menjadi laporan kepada dinas pendidikan. Agar menjadi bukti bahwa kegiatan belajar mengajar di sekolah sudah berjalan dengan baik. Anwar Prabu Mangkunegara menyatakan bahwa pengertian kinerja adalah hasil kerja secara kualitas dan kuantitas yang dicapai oleh seorang karyawan dalam melaksanakan tugasnya sesuai dengan tanggungjawab yang diberikannya. Anwar juga mendefinisi bahwa kinerja sebagai perilaku nyata yang ditampilkan oleh guru pada waktu memberikan pembelajaran kepada peserta didik di kelasnya. Kinerja guru dapat dilihat ketika dia melaksanakan proses belajar mengajar dikelas termasuk persiapannya baik dalam bentuk program semester maupun persiapan mengajar. ${ }^{47}$ Dalam hal mengawasi kinerja guru, tidak ada agenda khusus. Karenakan setiap guru-guru jika ada kegiatan yang menyebabkan tidak dapat melaksanakan tugas mengajar pasti terlebih dahulu ijin. Kemudian untuk mengawasi kegiatan guru di sekolah, Selebihnya dengan menilai daftar hadir sebagai bukti kehadiran guru.

d. Peningkatan motivasi kerja guru. Motivasi kerja guru merupakan dorongan atau keinginan yang timbul dari seseorang guru untuk mendidik, mengajar merencanakan, melaksanakan, dan menilai, membimbing, mengarahkan, dan melatih. Peserta didik dengan sebaik-baiknya dengan mengarahkan seluruh potensi yang ada. Motivasi yang tinggi dalam mengemban tugas akan menentukan kualitas dari pelayanan dan mutu pendidikan. Sehingga motivasi adalah suatu aspek yang sangat penting dimiliki oleh guru-guru.48 Adapun upaya yang dilakukan kepala SMAN 1 Damang Batu dalam memotivasi guru adalah, dengan melakukan monitoring secara rutin di sekolah. Bagi guru-guru yang piket, memberikan biaya konsumsi. Selebihnya melakukan komunikasi tentang apa saja kendala yang mungkin dihadapi guru-guru dan berusaha membantu memecahkan persoalan tersebut. Berdasarkan hasil wawancara tersebut dapat disimpulkan bahwa perhatian kepala sekolah terhadap motivasi guru di SMAN 1 Damang Batu cukup besar, dibuktikan dengan berbagai upaya motivasi yang telah dilakukan.

\section{Implikasi}

Strategi pembelajaran selama pandemic covid-19 sangat penting diperhatikan oleh guru Pendidikan Agama Kristen. Melalui penelitian ini diharapkan guru

47 Anwar Prabu Mangkunegara, Manajemen Sumber Daya Manusia (Bandung: Remaja Rosdakarya, 2010), 56.

48 http:/ / ejournal.unp.ac.id/ (diakses 19/08/2021, 18: 30 WIB) 
Pendidikan Agama Kristen tetap dalam melaksanakan tugasnya dengan baik, terutama dalam memberikan materi pelajaran dan dukungan kepada siswa selama pembelajaran masa pandemic covid-19 berlangsung. Dengan harapan, hasil belajar siswa tetap dalam terjaga dengan baik.

\section{Rekomendasi untuk Penelitian Lanjutan}

Penelitian ini dilakukan di salah satu SMA Negeri yang berada jauh di Kabupaten Gunung Mas, dimana sinyal internet masih sangat terbatas. Sehingga pembelajaran di masa pandemic covid-19 tidak dapat dilakukan secara online, dan hanya mengandalkan pemberian tugas yang dikumpulkan siswa ke sekolah. Berdasarkan kondisi penelitian ini, diharapkan ada penelitian lain yang melakukan penelitian lebih luas terkait kondisi sekolah yang lokasinya sulit jaringan internet.

\section{Kesimpulan}

Upaya sekolah dalam membantu guru melaksanakan strategi pembelajaran di masa pandemi covid-19 di SMAN 1 Damang Batu Kabupaten Gunung Mas. Dalam hal ini adalah upaya kepala sekolah diantaranya adalah, peningkatan motivasi kerja guru (Bagi guru-guru yang piket, memberikan biaya konsumsi), pengawasan kinerja guru (melakukan monitoring secara rutin di sekolah baik terhadap kinerja guru maupun aktivitas belajar peserta didik). Supervisi klinik, membantu guru menghadapi persoalan yang dihadapi selama proses belajar mengajar. Di masa pandemi menyediakan hand sanitizer, tong pencuci tangan dan sabun, serta masker bagi guruguru. Selanjutnya termometer gun untuk mengukur suhu. Memberikan kebijakan PJJ sesuai instruksi pemerintah, menginstruksikan guru-guru untuk membimbing siswa agar belajar dari rumah. Dengan memberi tugas. Agar dikerjakan oleh siswa selama berada di rumah.

\section{Rujukan}

Afifuddin dan Beni Ahmad Saebeni. Metodologi Penelitian Kualitatif. Bandung: CV Pustaka Setia, 2012.

Anitah, Sri. Strategi Pembelajaran di SD. Jakarta: Universitas Terbuka, 2007.

Arikunto, Suharsimi dan Lia Yuliana. Manajemen Pendidikan. Yogyakarta: Aditya Media, 2008.

Dick dan Carey. Komponen Strategi Pembelajaran. http:/ /Komponen strategi pembelajaran /2005/08/17/. Diakses tanggal 18 Agustus 2021 (03: 12 WIB) Ibrahim, Bafadal. Peningkatan Profesionalisme Guru Sekolah Dasar. Jakarta: Bumi Aksara, 2006.

Majid, Abdul. Perencanaan Pembelajaran. Bandung: Remaja Rosdakarya, 2008. 
Mangkunegara, Anwar Prabu. Manajemen Sumber Daya Manusia. Bandung: Remaja Rosdakarya, 2010.

Peraturan Menteri Kesehatan Republik Indonesia Nomor 9 Tahun 2020 tentang Pedoman Pembatasan Sosial Berskala Besar dalam rangka Percepatan Penanganan Corona Virus Disease 2019 (COVID-19), diakses dari (https:/ / covid19.go.id/p/ regulasi/ permenkes-no-9-tahun-2020-tentangpedoman-psbb-dalam-rangka-percepatan-penanganan-covid-19, pada tanggal 26 Februari 2021.

Permendikbud Nomor 24 Tahun 2012 tentang Penyelenggaraan Pendidikan Jarak Jauh pada Pendidikan Tinggi.

Sanjaya, Wina. Strategi Pembelajaran Berorientasi Standar Proses Pendidikan. Jakarta: Kencana Prenada Media Group, 2007.

Surat Edaran Sekretaris Jenderal No. 15 Tahun 2020 tentang Pedoman Pelaksanaan Belajar dari Rumah selama Darurat Bencana Corona Virus Disease (Covid19).

Undang-undang Nomor 14 Tahun 2005 tentang guru dan dosen.

Wena, Made. Strategi Pembelajaran Inovatif Kontemporer. Jakarta: Bumi Aksar, 2011.

Winataputra, Udin S. dkk. Strategi Belajar Mengajar. Jakarta: Pusat Penerbitan Universitas Terbuka, 2001. 